\title{
Food Preference and Consumption of Aquatic Macrophytes SubMerged By SNAIL Pomacea canaliculata ${ }^{1}$
}

\author{
Preferência Alimentar e Consumo de Macrófitas Aquáticas Submersas pelo Caramujo \\ Pomacea canaliculata
}

\author{
CRUZ, C. ${ }^{2,3}$, SILVA, A.F. ${ }^{3}$, VENTURINI, F.P..$^{3}$, GARLICH, N. ${ }^{3}$, PITELLI, R.L.C.M. ${ }^{3}$, and \\ PITELLI, R.A. ${ }^{3}$
}

\begin{abstract}
The objective of this study was to evaluate the consumption potential, food preference and use of snail Pomacea canaliculata as a biocontrol agent of four submerged aquatic macrophytes (Ceratophyllum demersum, Egeria densa, Egeria najas and Hydrilla verticillata). Two experiments were performed. In the first experiment, the introduction of a snail took place and 10 grams of each macrophyte in plastic containers with 1 liter of water. The assessments of consumption by the snail were performed at each 48 hours, during 12 days. The second experiment was performed in 600 liters microcosms containing five snails in each experimental unit. Fifty grams of each macrophyte were offered the snails at the same time, adding the same amounts after seven, 14, 21 and 30 days. On both trials, the most consumed macrophyte by the $P$. canaliculata was $H$. verticillata $(7.64 \pm 1.0 \mathrm{~g} 48 \mathrm{~h}$ and $50 \pm 0.18 \mathrm{~g})$ respectively, significantly differing from the others. However, in the absence of $H$. verticilata, E. najas and E. densa were consumed. The preference of $P$. canaliculata for $H$. verticillata is very interesting, because this plant is exotic and problematic in Brazil, and the snail is one more tool for biological management of submerged aquatic macrophyte H. verticillata.
\end{abstract}

Keywords: aquatic macrophytes, biological control, exotic species.

\begin{abstract}
RESUMO - O objetivo deste estudo foi avaliar o potencial de consumo, a preferência alimentar e o uso do caramujo Pomacea canaliculata como agente de biocontrole de quatro macrófitas aquáticas submersas (Ceratophyllum demersum, Egeria densa, Egeria najas e Hydrilla verticillata). Para isso, dois experimentos foram realizados. No primeiro, foi feita a introdução de um caramujo $e$ 10 gramas de cada macrófita em recipientes plásticos contendo 1 litro de água. A cada 48 horas foram realizadas avaliações do consumo do caramujo, no total de seis avaliações. O segundo experimento foi feito em microcosmos com capacidade para 600 litros de água, contendo cinco caramujos em cada unidade experimental. Cinquenta gramas de cada uma das macrófitas foram oferecidos aos caramujos ao mesmo tempo, acondicionando-se as mesmas quantidades após 7, 14, 21 e 30 dias. Tanto no primeiro quanto no segundo ensaio, a macrófita mais consumida por $\boldsymbol{P}$. canaliculata foi $\boldsymbol{H}$. verticillata $(7,64 \pm 1,0 \mathrm{~g} 48 \mathrm{~h})$, diferindo significativamente das demais. $\boldsymbol{H}$. verticillata $(50 \pm 0,18 \mathrm{~g})$ foi a planta preferida pelo caramujo no segundo experimento, em relação às demais macrófitas, porém, na ausência de $\boldsymbol{H}$. verticillata, $\boldsymbol{E}$. najas $e$ C. demersum foram consumidas. A preferência de $\boldsymbol{P}$. canaliculata por $\boldsymbol{H}$. verticillata é muito interessante, por esta planta ser exótica e problemática no Brasil, sendo o caramujo mais uma ferramenta para uso no manejo biológico da macrófita aquática submersa $\boldsymbol{H}$. verticillata.
\end{abstract}

Palavras-chave: plantas aquáticas, controle biológico, espécies exóticas.

Recebido para publicação em 19.3.2015 e aprovado em 20.4.2015.

UNIFEB, São Paulo, Brasil, <claudineicruz@gmail.com>; ${ }^{3}$ NEPEAM/FCAV/UNESP, Jaboticabal-SP, Brasil. 


\section{INTRODUCTION}

Aquatic macrophytes become a cause for concern when they form dense settlements, exceeding the environment's carrying capacity for their population and causing negative impacts to the multiple uses of water bodies. At high densities and high occupancy rates of the water body, the submersed macrophytes promote reduction of oxygen available in the water column, especially at night, with reflections on the local biological diversity, negatively affecting fish populations, and hindering fish catch, river transport, water sports and the generation of electricity (Borges Neto \& Pitelli, 2004; Mustafá et al., 2010; Souza, 2011).

Submersed macrophytes Ceratophyllum demersum, Egeria densa and Egeria najas are mentioned as the main problems in lakes and hydroelectric reservoirs in Brazil, especially in reservoir Jupiá (Mustafá et al., 2010). Hydrilla verticillata is a plant native to Asia recently introduced in Brazil, being initially identified in the Porto Primavera reservoir and considered an important lacustrine environment invasive exotic plant (Thomaz et al., 2012).

Among the management options for submerged plants in Brazil, biological control is an interesting option, since the only herbicide recorded for that vegetation is fluridone, but it requires water with low renewal rates for maintenance of concentration between 12 and $20 \mu \mathrm{g} \mathrm{L}^{-1}$ for about eight weeks (Fox et al., 1994); mechanical control is difficult at depths over $0.8 \mathrm{~m}$ and harmed by the large amount of dead trees submerged in the reservoirs (Velini et al., 2005).

Biological control of submerged aquatic plants is well studied using various organisms such as insects (Newman, 2004; Sullivan et al., 2011; Center et al., 2013); fish as Piaractus mesopotamicus (Miyazaki \& Pitelli, 2003) and grass carp Ctenopharyngodon idella (Gettys et al., 2009; Silva et al., 2014); microorganisms (Borges Neto \& Pitelli, 2004); and mollusks (Lach et al., 2000; Wong et al., 2010).

Snail Pomacea canaliculata originates in the tropical region of South America
(Estebenet \& Martín, 2003). Its diet consists of periphytons, macrophytes, debris and organic matter, and it changes its food preference during the ontogenetic development; it displays preference for detritus and algae when young, and for aquatic macrophytes, as adults (Hirai, 1988). This mollusk's eating habits involve numerous aquatic plants, and its food preference is basically defined by the ratio of availability of nitrogen, dry matter content, presence of defense substances and phenolic compounds of plants (Qui \& Kwong, 2009; Wong et al., 2010; Qui et al., 2011). This snail also eats some crops, such as Colocasia esculenta (Qui \& Kwong, 2009) and Oryze sativa (Halwart, 1994).

Considering such organism as a native of South America and efficient as a predator of submerged plants and with numerous natural biological control agents (Bergmann et al., 2013), which maintain their populations within densities that cause no problems, a hypothesis is presented to evaluate their use in the biological control of endemic macrophytes and the exotic invasive $H$. verticillata, which is rapidly expanding in many reservoirs in Brazil, such as Porto Primavera (Pitelli et al., 2014) and Nova Avanhandava (Watanabe et al., 2011), using the inundative strategy.

In order to analyze this biological control program viability, a lot of research should be conducted to assess whether the strategy will be effective and ensure that there are no risks to the environment and to human activities. One of the first information to be obtained is the position of $H$. verticillata in this snail's feeding preference and the respective biomass consumption compared to native plants, which occur in the reservoirs. The objective of this study was to compare $P$. canaliculata feeding activity in $H$. verticillata and in natives plant E. densa, E. najas and C. demersum, cohabiting rivers Paraná and Tietê basins reservoirs.

\section{MATERIALS AND METHODS}

The consumption and feeding preference of the snail $P$. canaliculata by submerged macrophytes were evaluated by conducting two tests.

In the first experiment, the plants were tendered separately, and the study was 
conducted in a room with controlled temperature of $25.0 \pm 1.5^{\circ} \mathrm{C}$ and photoperiod of $12 \mathrm{~h}$. A plastic container with one liter of water and an adult snail with an average weight of $24.09 \pm 7.36 \mathrm{~g}$ were used; then $10 \mathrm{~g}$ of biomass of each aquatic macrophyte were offered. For weighing the plants, the excess water accumulated on the surface was removed with a light pressure with an absorbent paper and the biomass was measured on an analytical balance (0.5-2000 g, brand Marte $^{\circledR}$, mod. AS 2000 C). The test was conducted for 12 days, and the evaluation of the plants was performed every 48 hours. In each evaluation, the remaining biomass was weighed and discarded. Then, a new amount of 10 grams was offered to the snail for another 48 hours of predation and six evaluations were held. Each vial was considered an experimental unit, and the containers were arranged in a completely randomized design with five replications.

The second experiment evaluated the consumption and feeding preference of $P$. canaliculata by aquatic macrophytes C. demersum, E. densa, E. najas and $H$. verticillata, when offered at the same time. This experiment was conducted in mesocosms with a capacity of 600 liters, with a continuous flow of water around $8.1 \mathrm{~L} \mathrm{~h}^{-1}$. In each mesocosm were offered $50 \mathrm{~g}$ of each macrophyte, which were randomly distributed. In each mesocosm, five adult snails were placed, weighing in average $150.44 \pm$ 12.06 grams. Mesocosms were distributed in a completely randomized design with 10 repetitions.

Consumption assessments of the macrophytes were performed at 7, 14, 21 and 30 days of trial. In these assessments, the remaining biomass in each mesocosm was determined on an analytical balance and then these leftovers were discarded, and again $50 \mathrm{~g}$ of each species were offered.

The snails used in this test were raised in 250 liters boxes with the bottom filled with compost soil sediment, organic matter and sand $(1: 1: 1 \mathrm{v} / \mathrm{v})$. In these boxes, the water flow was kept constant (average of $7.3 \mathrm{~L} \mathrm{~h}^{-1}$ ). The boxes were covered with shading screen to avoid predation of the snails. Feeding was daily, with diversified aquatic macrophytes and commercial feed. The macrophytes used in the study were collected in the collection of Nepeam Unesp.

Macrophyte consumption was calculated by the biomass reduction percentage relative to the amount offered at the beginning of each period. At the end of the experiment, these data were submitted to analysis of variance and compared by Tukey test at 5\% probability.

\section{RESULTS AND DISCUSSION}

Snail $P$. canaliculata showed a higher consumption of $H$. verticillata, with an average of $7.64 \pm 1.0 \mathrm{~g}$ in 48 hours of exposure. This value was significantly higher than the consumption level for other plants. The consumption of $E$. najas was of $3.63 \pm 0.77 \mathrm{~g}$, being statistically higher than that observed for the two other plants offered: E. densa and $C$. demersum. The average consumption of $E$. densa was of $1.58 \pm 1.00 \mathrm{~g}$, and of C. demersum, $1.26 \pm 0.56 \mathrm{~g}$, in the period of 48 hours; significant differences among these values were not detected by the adopted statistical model.

The consumptions of $H$. verticillata (3.82 g day $\left.^{-1}\right)$, E. najas (1.81 g day $\left.^{-1}\right)$, E. densa $\left(0.79 \mathrm{~g} \mathrm{day}^{1}\right)$ and $C$. demersum $\left(0.63 \mathrm{~g}\right.$ day $\left.^{-1}\right)$ for $P$. canaliculata were lower than the ones observed for Lemna minor (5.4 $\left.\mathrm{g} \mathrm{day}^{-1}\right)$; Eichhornia crassipes (3.0 $\left.\mathrm{g} \mathrm{day}^{-1}\right)$ and Ipomoea aquatica $\left(0.32 \mathrm{~g} \mathrm{day}^{-1}\right)$, according to what was observed by Carlsson \& Lacoursière (2005), and also for C. demersum (6.51 $\left.\mathrm{g} \mathrm{day}^{-1}\right)$, $H$. verticillata $\left(2.50 \mathrm{~g} \mathrm{day}^{-1}\right)$ and $E$. densa (0.46 g day $\left.^{-1}\right)$, performed by snail Pomacea insularium (Baker et al., 2010). These differences are related to the development conditions of the experiments and snails sizes used.

In the reduction of the biomass supplied, there was a difference among the four studied macrophytes. The average biomass reduction of $H$. verticillata was of $75.25 \pm 9.53 \%$, against $35.53 \pm 8.33 \%$ for E. najas, $17.27 \pm 9.94 \%$ for $E$. densa and $12.53 \pm 5.73 \%$ for $C$. demersum (Figure 1). In the two most preyed species there was little variation in the amounts consumed in periods of 48 hours, and the consumption ratio between them was almost the same in the period of the observations. As 
" $H$. verticillata $\square$ E. najas $\quad E$. densa $\equiv C$. demersum

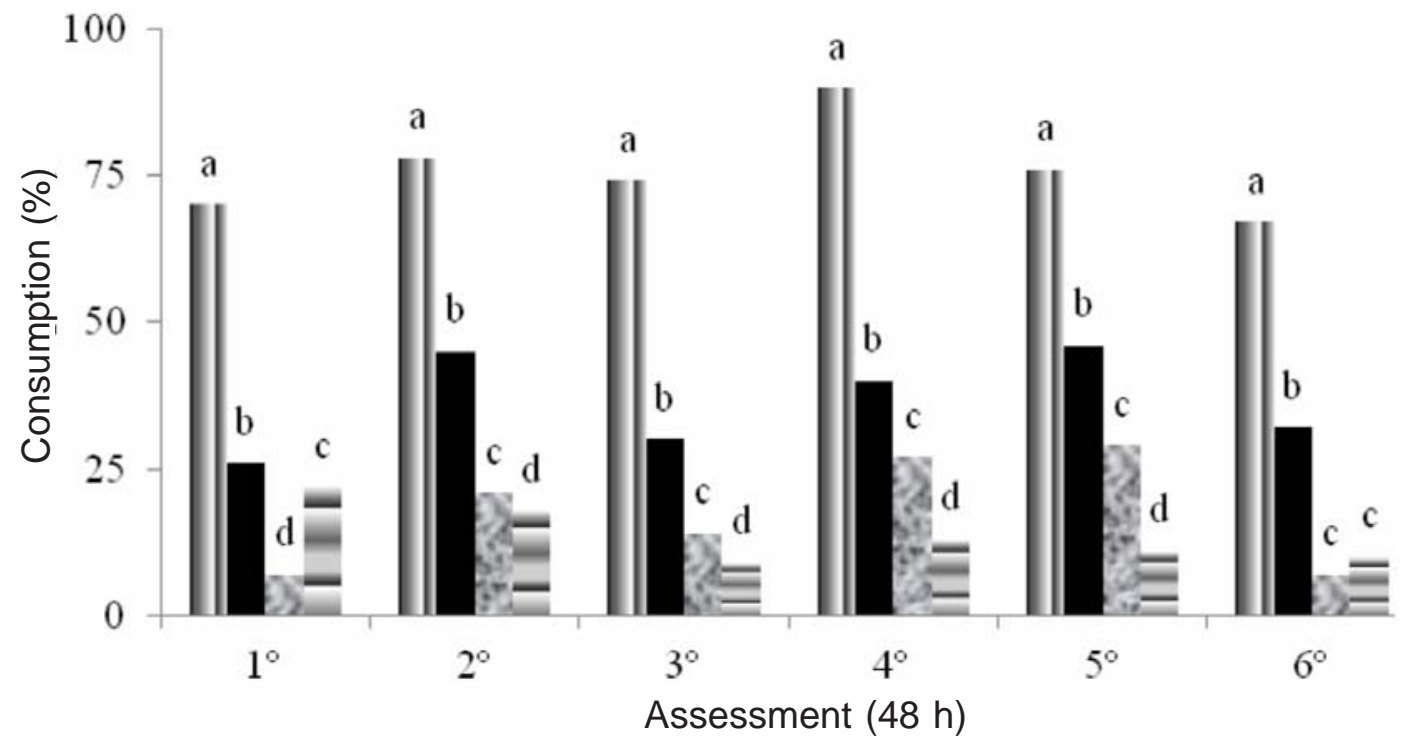

Figure 1 - Percentage of consumption of aquatic macrophytes by snail Pomacea canaliculata in a bioassay room.

for the relationship between $E$. densa and C. demersum, more profound changes occurred in the trial period. In the first period, the consumption of Ceratophyllaceae was higher than the consumption of $E$. densa. In the fourth and fifth periods, the relative consumption was reversed, with higher predation of Hydrocharitaceae in relation to C. demersum. In the other observations, the quantities consumed by these two species showed small differences.

During the assessment period (12 days), the snails fed with $H$. verticillata had the greatest increases in body mass, with gain, on average, of $0.46 \mathrm{~g} \mathrm{day}^{-1}$. Animals fed with $C$. demersum and $E$. densa had mass reduction of $0.15 \mathrm{~g}$ and $0.02 \mathrm{~g} \mathrm{day}^{-1}$, respectively. Individuals fed $E$. najas showed a small weight gain: $0.09 \mathrm{~g}$ day $^{-1}$.

In terms of biological control sustainability, there is probably viability of targeting only for $H$. verticillata, the species in which this snail obtains resources for growth and development. In the other macrophytes offered, probably the snail should seek alternative sources of food to obtain the amount of carbon and energy to ensure the growth of individuals and population, which undermines its selectivity, since these results were obtained with the snail feeding behavior when it was restricted to only one species for predation.

In the second experiment, the macrophytes were offered at the same time, and the snail had the possibility of having free choice and expressing its food preference. In these conditions, $H$. verticillata was also the most consumed macrophyte by $P$. canaliculata $(50 \pm 0.18 \mathrm{~g})$, being significantly higher than the verified for E. najas (13.02 $\pm 6.70 \mathrm{~g})$ and C. demersum $(6.16 \pm 6.55 \mathrm{~g})$. In the presence of these three mentioned macrophytes there was not consumption of E. densa. This last result is quite interesting because it confirms data reported by Pitelli et al. (2014), according to which in areas cohabited by these submerged macrophytes, E. densa stands out in the community and is the most problematic species in CESP reservoirs (Mustafá et al., 2010), where this snail has a significant population. Importantly, $P$. canaliculata is a native and endemic species in these reservoirs (Bergmann et al., 2013). Low food preference of this snail for Elodea canadensis was also verified (Estebenet, 1995).

$H$. verticillata had $100 \%$ of its initial biomass consumed. For other species, the consumption percentages were $25.83 \%$ for E. najas and $12.23 \%$ for C. demersum. In a 
study by Carlsson \& Lacoursière (2005), the food preference of $P$. canaliculata for floating macrophytes was: L. minor $>$ E. crassipes > I. aquatica; L. minor was reduced by $90 \%$ of the initial biomass supplied, while for $H$. verticillata, in this work, the reduction was 100\% (Figure 2).

$P$. canaliculata is recognized for having great herbivory power and low selectivity (Lach et al., 2000; Carlsson \& Lacoursière, 2005; Carlsson \& Brönmark, 2006). However, their food preference can be a tool in the management of $H$. verticillata, using the inundative strategy. This strategy provides for the release of a significant number of animals to increase herbivory pressure against the target species and produces almost immediate reflection in the reduction of its population. There is no risk that, after its release, the population density of the animal remains at a high value, because the environment selection pressure by natural enemies rapidly increases, and the storage capacity of the snail goes back to its original condition. Achieving population reduction, new growth of the macrophyte may occur - in this case, the inundative release may again become relevant.
This is a hypothesis to be tested in future work on a research program to investigate aspects of mollusk biology and its behavior towards common species of macrophytes in water bodies where control of $H$. verticillata will be effected. It is also very interesting to note that when fed other with other submersed macrophytes tested, the snail has no growth, which facilitates the reduction of its population for the storage capacity of the environment. Thus, the results obtained in this study are similar to the ones found by other authors (Estebenet, 1995; Lach et al. 2000; Carlsson \& Lacoursière, 2005; Carlsson \& Brönmark, 2006) and indicate that $P$. canaliculata actively selects its food and displays a clear preference for certain species of macrophytes.

According to the data obtained, the snail $P$. canaliculata has great herbivory power and can be used as a biocontrol agent for submerged aquatic macrophytes, not allowing large single-species or poorly diversified populations to predominate in Brazilian reservoirs (Mori et al., 1999; Sousa, 2011). Therefore, further studies on natural enemies that control the population of this mollusk in inland waters in Brazil, such as fish (Sin, 2006;

\section{II $H$. verticillata $\square$. najas $\square E$. densa $\equiv C$. demersum}

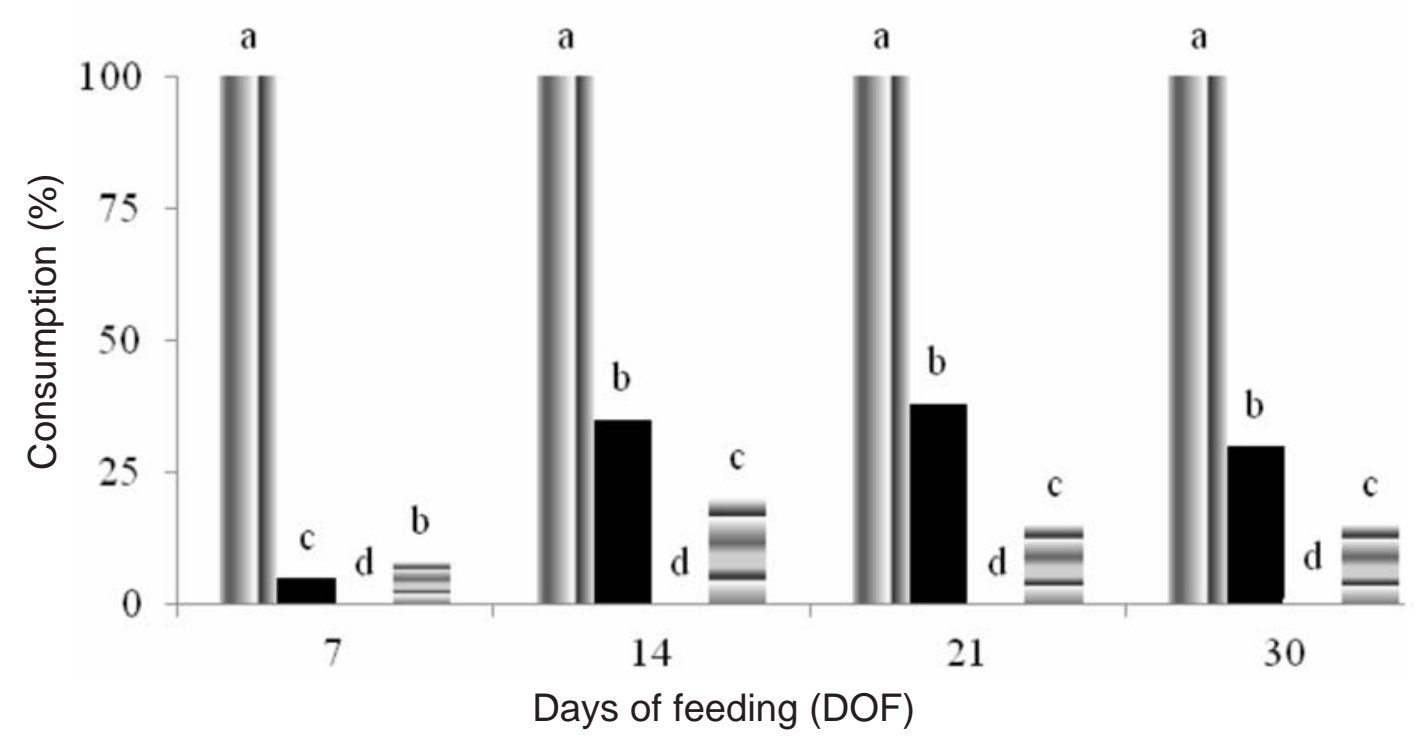

Figure 2 - Percentage of consumption and food preference of snail Pomacea canaliculata by submerged aquatic macrophytes offered at the same time in microcosms. 
Wong et al., 2009) and hawk Rostrhamus sociabilis (Bergmann et al., 2013) will also be important.

The results of these experiments allow us to infer that there is a potential for use of this snail in the biological control of $H$. verticillata by inundative or repositioning strategies. This latter strategy is used with grass carp, which is a herbivorous fish, but with food preference for some species. The animal load placed is planned to control only the target species (Gettys et al., 2009).

Further studies may establish the possibility of using $P$. canaliculata in the biological control of $H$. verticillata by repositioning strategy. This hypothesis is based on the fact that this snail is endemic in water bodies in Brazil, and the invasive exotic plant $H$. verticillata is not desired.

Thus, it is concluded that $P$. canaliculata has potential for use as a biocontrol organism of submerged aquatic macrophyte $H$. verticillata.

\section{LITERATURE CITED}

BAKER, P. et al. Feeding rates of an introduced freshwater gastropod Pomacea insularum on native and non-indigenous aquatic plants in Florida. J. Mollus. Stud., v. 76, n. 1, p. 1-6, 2010.

BERGMANN, F. B. et al. Foraging activity of the snail kite, Rostrhamus sociabilis (Aves: Accipitridae) in wetlands of southern Brazil. J. Braz. Biol., v. 73, n. 2, p. 245-252, 2013.

BORGES, N.; PITELLI, R. A. Adjuvantes e herbicidas e a infectividade de Fusarium graminearum, agente potencial de biocontrole de Egeria densa e Egeria najas. Planta Daninha, v. 22, n. 1, p. 77-83, 2004.

CARLSSON, N. O. L.; LACOURSIÈRE, J. Herbivory on aquatic vascular plants by the introduced golden apple snail (Pomacea canaliculata) in Lao PDR. Biol. Invas., v. 7, n. 2, p. 233-241. 2005.

CARLSSON, N. O. L.; BRÖNMARK, C. Size dependent effects of an invasive herbivorous snail (Pomacea canaliculata) on macrophytes and periphyton in Asian wetlands. Freshwater Biol., v. 51, n. 4, p. 695-704, 2006.

CENTER, T. D. et al. Evidence of establishment of Bagous hydrillae (Coleoptera: Curculionidae), a biological control agent of Hydrilla verticillata (Hydrocharitales:

Hydrocharitaceae) in north America. Florida Entomol., v. 96, n. 1, p. 180-186, 2013.
ESTEBENET, A. L. Food and feeding in Pomacea canaliculata (Gastropoda: Ampullariidae). The Veliger, v. 38, n. 4, p. 277-283, 1995.

ESTEBENET, A. L.; MARTÍN, P. R. Shell interpopulation variation and its origin in Pomacea canaliculata (Gastropoda: Ampullaridae) from southern pampas, Argentina. J. Mollus. Stud., v. 69, n. 4, p. 301-310, 2003.

FOX, A. M. et al. Use of fluridone for hydrilla management in the Withlacoochee River, Flórida. J. Aquatic. Plant Manag., v. 32, n. 1, p. 47-55, 1994.

GETTYS, L. A. et al Biology and control of aquatic plant: A best management practices handbook. Aquatic Ecosystem Restoration Foundation, 2009. 210 p.

HALWART, M. The golden apple snail Pomacea canaliculata in Asian rice farming systems: present impact and future threat. Inter. J. Pest Manag., v. 40, n. 1, p. 199-206, 1994.

HIRAI, Y. Apple snail in Japan: the present status and management. JARQ Japan, v. 22, n. 1, p. 161-165, 1988.

LACH, L. et al. Food preference and reproductive plasticity in an invasive freshwater snail. Biol. Invas., v. 2, n. 4 , p. 279-288, 2000.

MIYAZAKI, D. M. Y.; PITELLI, R. A. Estudo do potencial do pacu (Piaractus mesopotamicus) como agente de controle biológico de Egeria densa, E. najas e Ceratophyllum demersum. Planta Daninha, v. 21, p. 53-59, 2003. (Edição Especial)

MORI, E. S. et al. Caracterização genética de populações de Egeria najas presente no reservatório de jupiá e rios afluentes. Planta Daninha, v. 17, n. 2, p. 217-225, 1999.

MUSTAFÁ, A. L. et al. A experiência da CESP no manejo e controle de macrófitas no reservatório da UHE Souza Dias (Jupiá). Ação Amb., v. 13, n. 43, p. 17-26, 2010.

NEWMAN, R. M. Invited review: Biological control of Eurasian watermilfoil by aquatic insects: basic insights from an applied problem. Archiv Fuer Hydrobiol., v. 159, n. 2, p. 145-184, 2004.

PITELLI, R. L. C. M. et al. Aquatic plant community in Porto Primavera Reservoir. Planta Daninha, v. 32, n. 3, p. 467-473, 2014.

QIU, J. W.; KWONG, K. L. Effects of macrophytes on feeding and life-history traits of the invasive apple snail Pomacea canaliculata. Freshwater Biol., v. 54, n. 8, p. 1720-1730, 2009. 
QIU, J. W. et al. Consumption, survival and growth in the invasive freshwater snail Pomacea canaliculata: does food freshness matter? J. Mollus. Stud., v. 77, n. 2, p. 189-195, 2011.

SILVA, A. F. et al. Utilização da carpa capim (Ctenopharyngodon idella) como agente de controle biológico de macrófitas aquáticas submersas.

Planta Daninha, v. 32, n. 4, p. 765-773, 2014.

SIN, T. S. Evaluation of different species of fish for biological control of golden apple snail Pomacea canaliculata (Lamark) in rice. Crop Protec., v. 25, n. 9, p. 1004-1012, 2006.

SOUSA, W. T. Z. Hydrilla verticillata (Hydrocaritaceae), a recent invader threatening Brazil's freshwater environments: a review of the extent of the problem. Hidrobiologia, v. 669, n. 1, p. 1-20, 2011.

SULLIVAN, P. R. et al. Biological control of salvinia molesta by Cyrtobagous salviniae in temperate Australia.

Biol. Control, v. 57, n. 3, p. 222-228, 2011.
THOMAZ, S. M. et al. Using space-for-time substitution and time sequence approaches in invasion ecology. Freshwater Biol., v. 57, n. 11, p. 2401-2410, 2012.

VELINI, E. D. et al. Avaliação operacional do controle mecânico de plantas aquáticas imersas no reservatório de jupiá. Planta Daninha, v. 23, n. 2, p. 277-285, 2005.

WATANABE, F. S. et al. Caracterização de plantas aquáticas submersas a partir de dados de espectrorradiômetro no Reservatório de Nova Avanhandava - Rio Tietê/SP. In: SIMPÓSIO BRASILEIRO DE SENSORIAMENTO REMOTO, 15², 2011, Curitiba. Anais... Curitiba: 2011. p. 5800-5807.

WONG, P. K. et al. Complex interactions among fish, snails and macrophytes: implications for biological control of an invasive snail. Biol. Invas., v. 11, n. 10, p. 2223-2232, 2009.

WONG, P. K. et al. Palatability of macrophytes to the invasive freshwater snail Pomacea canaliculata: differential effects of multiple plant traits. Freshwater Biol., v. 55, n. 10, p. 2023-2031, 2010. 